\title{
Ferrimicrobium acidiphilum gen. nov., sp. nov. and Ferrithrix thermotolerans gen. nov., sp. nov.: heterotrophic, iron-oxidizing, extremely acidophilic actinobacteria
}

Correspondence

D. Barrie Johnson

d.b.johnson@bangor.ac.uk

\author{
D. Barrie Johnson, Paula Bacelar-Nicolau, $†$ Naoko Okibe, $\ddagger$ \\ Angharad Thomas and Kevin B. Hallberg
}

School of Biological Sciences, College of Natural Sciences, Bangor University, Bangor LL57 2UW, UK

\begin{abstract}
Two novel extremely acidophilic, iron-oxidizing actinobacteria were isolated, one from a mine site in North Wales, UK (isolate $T 23^{\mathrm{T}}$ ), and the other from a geothermal site in Yellowstone National Park, Wyoming, USA $\left(\mathrm{YOO5}^{\mathrm{T}}\right)$. These new actinobacteria belong to the subclass Acidimicrobidae, and in contrast to the only other classified member of the subclass (Acidimicrobium ferrooxidans), both isolates were obligate heterotrophs. The mine site isolate was mesophilic and grew as small rods, while the Yellowstone isolate was a moderate thermophile and grew as long filaments, forming macroscopic flocs in liquid media. Both isolates accelerated the oxidative dissolution of pyrite in yeast extract-amended cultures, but neither was able to oxidize reduced forms of sulfur. Ferrous iron oxidation enhanced growth yields of the novel mesophilic actinobacterium $\mathrm{T}^{2}{ }^{\top}$, though this was not confirmed for the Yellowstone isolate. Both isolates catalysed the dissimilatory reduction of ferric iron, using glycerol as electron donor, in oxygen-free medium. Based on comparative analyses of base compositions of their chromosomal DNA and of their 16S rRNA gene sequences, the isolates are both distinct from each other and from Acidimicrobium ferrooxidans, and are representatives of two novel genera. The names Ferrimicrobium acidiphilum gen. nov., sp. nov. and Ferrithrix thermotolerans gen. nov., sp. nov. are proposed for the mesophilic and moderately thermophilic isolates, respectively, with the respective type strains

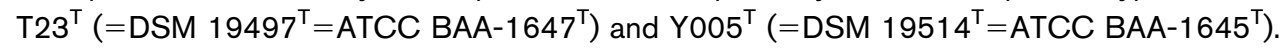

\section{INTRODUCTION}

Actinobacteria are high- $G+C$, Gram-positive bacteria, comprising a wide range of physiologically diverse species. The Acidimicrobidae, a subclass within the actinobacteria (Stackebrandt et al., 1997), is currently represented by only a single genus (Acidimicrobium) and a single species (Acidimicrobium ferrooxidans). Acidimicrobium ferrooxidans is a moderately thermophilic, iron-oxidizing acidophile (Clark \& Norris, 1996), and was first isolated (strain

†Present address: Universidade Aberta, 1269-001-Lisboa, Portugal.

‡Present address: Research Institute for Innovative Technology for the Earth (RITE), Kyoto, Japan.

Abbreviation: RuBisCO, ribulose-1,5-bisphosphate carboxylase/oxygenase.

The GenBank/EMBL/DDBJ accession numbers for the 16S rRNA gene sequences of Ferrimicrobium acidiphilum and Ferrithrix thermotolerans are AF251436 and AY140237, respectively.

Supplementary figures showing pyrite oxidation and reduction of ferric iron by isolates $\mathrm{T}^{2} 3^{\mathrm{T}}$ and $\mathrm{Y} 005^{\mathrm{T}}$ are available with the online version of this paper.
TH3) from a copper leaching operation in New Mexico, USA (Brierley, 1978). A second strain $\left(\mathrm{ICP}^{\mathrm{T}}\right)$, isolated from a geothermal site in Iceland by enriching in a pyritecontaining medium, was selected as the type strain of the species by Clark \& Norris (1996). Since then, there have been few reports of the isolation of Acidimicrobium-like bacteria. Interestingly, novel Acidimicrobidae were shown, by $16 \mathrm{~S}$ rRNA gene community analysis, to be major components of the bacterial community associated with two species of sponge (Xestospongia spp.) and were hypothesized to form symbiotic associations with the animals (Montalvo et al., 2005).

Initially Acidimicrobium ferrooxidans was considered to be an obligate heterotroph, but later Clark \& Norris (1996) showed unequivocally that it could fix carbon dioxide when grown in organic carbon-free media. Mesophilic iron-oxidizing acidophilic bacteria that have an absolute requirement for organic carbon have also been described (Johnson \& Roberto, 1997). These bacteria were shown to use organic carbon (such as yeast extract) included in growth media when grown in pure culture, or to use that 
derived from chemolithotrophic primary producers when grown as mixed cultures with other iron and sulfur oxidizers (Bacelar-Nicolau \& Johnson, 1999). More recently, a variety of moderately thermophilic acidophiles (including a strain of Acidimicrobium ferrooxidans) were isolated from acidic geothermal sites in Yellowstone National Park, Wyoming, USA (Johnson et al., 2003). One of these isolates $\left(\mathrm{Y}_{00} 5^{\mathrm{T}}\right)$ was originally described (on the basis of erroneous 16S rRNA gene sequencing) as being related to methylotrophic betaproteobacteria. However, resequencing of the isolate confirmed that it too (like isolate $\mathrm{T} 23^{\mathrm{T}}$ ) was an actinobacterium.

Here we describe the physiological and phylogenetic characteristics of obligately heterotrophic, iron-oxidizing actinobacteria, for which two novel genera are proposed.

\section{METHODS}

Isolation, purification and cultivation of bacteria. Bacterium $\mathrm{T} 23^{\mathrm{T}}$ was isolated from pyrite enrichment cultures inoculated with mine water from the abandoned Cae Coch sulfur mine, North Wales, UK (Jenkins \& Johnson, 1993), as described previously (BacelarNicolau \& Johnson, 1999) and $\mathrm{Y}_{005^{\mathrm{T}}}$ from an iron/yeast extract enrichment culture inoculated with mineral sample ( $\left.\mathrm{pH} 2.7 ; 31{ }^{\circ} \mathrm{C}\right)$ taken in the Beryl Spring/Gibbon river area of Yellowstone National Park (Johnson et al., 2003). In both cases, isolates were obtained by streaking enrichment cultures onto overlaid solid media designed to cultivate acidophilic prokaryotes (Johnson \& Hallberg, 2007), and were purified by repeated plating and selection of single colonies. The solid media used contained (i) ferrous iron ('iFeo'); (ii) ferrous iron and tryptone soya broth ('Feo'); (iii) ferrous iron, tryptone soya broth and potassium tetrathionate ('FeSo'). Both bacteria were routinely subcultured in liquid media containing $10 \mathrm{mM}$ ferrous sulfate and $0.02 \%(\mathrm{w} / \mathrm{v})$ yeast extract at $\mathrm{pH} 2.0$. Isolate $\mathrm{T} 23^{\mathrm{T}}$ was grown routinely at $30{ }^{\circ} \mathrm{C}$ and $\mathrm{Y} 005^{\mathrm{T}}$ at $45{ }^{\circ} \mathrm{C}$. Cultures of Acidimicrobium ferrooxidans (the type strain, $\mathrm{ICP}^{\mathrm{T}}$, and strain $\mathrm{TH} 3$ ) were kindly provided by $\mathrm{Dr}$ Paul Norris of the University of Warwick, UK. Other bacteria used were maintained in the Acidophile Culture Collection at the authors' laboratory.

Microscopy. Bacteria were viewed using a phase-contrast microscope (Leitz Labolux, $\times 400$ ) and an Hitachi S-520 scanning electron microscope. Sample preparation for the latter was as described by Johnson et al. (1992).

Oxidation of ferrous iron, sulfur and pyrite. Isolates $\mathrm{T} 23^{\mathrm{T}}$ and Y $005^{\mathrm{T}}$ were grown in $10 \mathrm{mM}$ ferrous iron $/ 0.02 \%(\mathrm{w} / \mathrm{v})$ yeast extract liquid medium in shake flask cultures, incubated at either $30{ }^{\circ} \mathrm{C}$ $\left(\mathrm{T} 23^{\mathrm{T}}\right)$ or $45{ }^{\circ} \mathrm{C}\left(\mathrm{Y}_{005^{\mathrm{T}}}\right)$. Cells were harvested and suspended in mineral salts (at $\mathrm{pH} 2.0$ ). To confirm ferrous iron oxidation, cultures containing $25 \mathrm{mM}$ ferrous sulfate $(\mathrm{pH} \mathrm{1.9)}$ were inoculated, and ferrous iron concentrations measured at regular intervals using the ferrozine assay (Lovley \& Phillips, 1987). For sulfur oxidation, the cultures contained $0.5 \%(\mathrm{w} / \mathrm{v})$ of finely ground elemental sulfur in place of iron, while the oxidation of pyrite $\left(\mathrm{FeS}_{2}\right)$ was assessed in media containing $1 \%(\mathrm{w} / \mathrm{v})$ of the mineral, pre-treated with hydrochloric acid to remove any oxidized surface layers. Sulfur oxidation was monitored by measuring changes in culture $\mathrm{pH}$ (oxidation of sulfur to sulfate is an acid-generating reaction), and pyrite oxidation by recording changes in concentrations of soluble total iron, either by atomic absorption spectrophotometry or using ion chromatography. Duplicate cultures, amended, or not, with $0.02 \%$ yeast extract were set up in each case.
Determination of $\mathbf{p H}$ and temperature optima. Growth of isolates $\mathrm{T} 23^{\mathrm{T}}$ and $\mathrm{Y}_{005^{\mathrm{T}}}$ at different temperatures and $\mathrm{pH}$ values was tested in a 21 bioreactor run in batch mode. The growth medium for both bacteria contained ferrous iron $(25 \mathrm{mM})$ and yeast extract $(0.02 \%)$. Growth rates at a specific temperature and $\mathrm{pH}$ were determined from semi-logarithmic plots of iron oxidized against time.

Utilization of organic substrates. Bacteria were grown in a liquid medium containing $10 \mathrm{mM}$ ferrous sulfate and $0.01 \%$ yeast extract. Various organic materials were added to this medium, at concentrations of between 5 and $15 \mathrm{mM}$ (in order to provide similar amounts of organic carbon). The organic compounds tested were: (i) sugars (glucose, fructose, ribose, glucosamine and glucuronic acid); (ii) alcohols (ethanol and glycerol); (iii) acids (citric and acetic); and (iv) amino acids (glycine and glutamic acid). Bacterial growth was determined by measuring optical densities at $600 \mathrm{~nm}$ (isolate $\mathrm{T} 23^{\mathrm{T}}$ ) or protein concentrations [isolate $\mathrm{Y} 005^{\mathrm{T}}$, using the method described by Bradford (1976)] and comparing them to control cultures containing only ferrous iron and yeast extract. Subsequently, growth was tested in yeast extract-free glycerol medium in order to ascertain whether the isolates required specific organic growth factors. The toxicity of acetic acid to the bacteria was tested by adding this organic acid at concentrations of between $100 \mu \mathrm{M}$ and $10 \mathrm{mM}$ to a liquid medium containing $10 \mathrm{mM}$ ferrous iron and $0.02 \%$ yeast extract, and recording bacterial growth and iron oxidation.

Reduction of ferric iron. Bacteria were grown in $10 \mathrm{mM}$ ferrous sulfate $/ 0.01 \%$ yeast extract ( $\mathrm{pH} 2.0$ ) liquid medium in foamstoppered universal bottles, incubated (shaken) at $30^{\circ}$ or $45{ }^{\circ} \mathrm{C}$ under aerobic conditions. When all of the ferrous iron had been oxidized to ferric iron, glycerol was added (to a final concentration of $5 \mathrm{mM}$ ) and the bottles transferred to an anaerobic jar and incubated under anaerobic conditions (unshaken) using the AnaeroGen system (Oxoid). Samples were taken from the cultures at regular intervals and ferrous iron concentrations measured. Non-inoculated cultures were set up as controls.

Effect of ferrous and ferric iron concentrations on biomass yields and growth rates. In order to ascertain whether ferrous iron oxidation by isolates $\mathrm{T} 23^{\mathrm{T}}$ and $\mathrm{Y} 005^{\mathrm{T}}$ was an energy-generating reaction, cultures were set up (at $\mathrm{pH} 1.9$, in triplicate) containing $0.02 \%(\mathrm{w} / \mathrm{v})$ yeast extract and different concentrations of either ferrous sulfate or ferric sulfate $(0.1-50 \mathrm{mM})$. These were incubated under aerobic conditions (shaken at 30 or $45{ }^{\circ} \mathrm{C}$ ) and, when all of the iron in the $50 \mathrm{mM}$ cultures had been oxidized, cells were harvested, inorganic precipitates dissolved (by addition of sulfuric acid) and total protein yields determined using the Bradford assay. A second experiment, set up with $\mathrm{T} 23^{\mathrm{T}}$ only, measured the effect of different concentrations of ferrous and ferric iron on the growth rate of this isolate. Ferrous (or ferric) sulfate was added to final concentrations of $1,10,25$ or $50 \mathrm{mM}$ to $0.02 \%$ yeast extract/mineral salts medium in $100 \mathrm{ml}$ shake flasks. Cultures were incubated at $30{ }^{\circ} \mathrm{C}$ and growth rates determined by measuring changes in optical densities (at $600 \mathrm{~nm})$ and ferrous iron concentrations.

Heavy metal tolerance. Isolates $\mathrm{T} 23^{\mathrm{T}}$ and $\mathrm{Y} 005^{\mathrm{T}}$ were tested for the abilities to grow and oxidize iron in the presence of elevated concentrations of copper, zinc and ferrous and ferric iron. Concentrations of between 10 and $200 \mathrm{mM}$ of each of these metals were added to standard ferrous iron/yeast extract medium, and bacterial numbers (cell counts using a Thoma counting chamber) and ferrous iron concentrations (using ferrozine) were recorded.

Autotrophic growth and screening of RuBisCo (ribulose-1,5bisphosphate carboxylase/oxygenase) genes. Isolates $\mathrm{T} 23^{\mathrm{T}}$ and $\mathrm{Y} 005^{\mathrm{T}}$ were tested for their abilities to grow in 'inorganic' ferrous sulfate medium (i.e. without any added organic material). In 
addition, $\mathrm{CO}_{2}$ assimilation by isolate $\mathrm{T} 23^{\mathrm{T}}$ was examined using two variants of a method described by Ghauri \& Johnson (1991). In the first of these, isolate $\mathrm{T} 23^{\mathrm{T}}$ and the type strain of the autotrophic iron oxidizer Acidithiobacillus ferrooxidans (ATCC $23270^{\mathrm{T}}$ ) as a positive control, were grown in $20 \mathrm{mM}$ ferrous sulfate medium supplemented or not with $0.02 \%$ yeast extract in sealed flasks containing ${ }^{14} \mathrm{CO}_{2}$, and measurements were made of the amounts of labelled carbon assimilated. In the second experiment, isolate $\mathrm{T} 23^{\mathrm{T}}$ was grown to late exponential phase in ferrous sulfate/yeast extract medium, and cells were harvested, washed and resuspended in $20 \mathrm{mM}$ ferrous sulfate medium containing ${ }^{14} \mathrm{CO}_{2}$. A corresponding culture of Acidithiobacillus ferrooxidans grown in $20 \mathrm{mM}$ ferrous sulfate medium was used as a control. The cell numbers in the inoculated cultures were $4.1 \times 10^{7} \mathrm{ml}^{-1}$ (isolate $\mathrm{T} 23^{\mathrm{T}}$ ) and $1.8 \times 10^{7} \mathrm{ml}^{-1}$ (Acidithiobacillus ferrooxidans).

Isolates $\mathrm{T} 23^{\mathrm{T}}$ and $\mathrm{Y} 005^{\mathrm{T}}$ were screened by PCR for the presence of the RuBisCO large subunit-encoding genes $c b b L$ and $c b b M$. Cell lysates, prepared for $16 \mathrm{~S}$ rRNA gene sequence analysis (see below), were used as templates, and the primers used were those described by Alfreider et al. (2003). PCR was carried out using PCR Master Mix (Promega), to which $\mathrm{MgCl}_{2}$ was added to a final concentration of $3.5 \mathrm{mM}$ for both genes, for 35 cycles of $95{ }^{\circ} \mathrm{C}$ for $30 \mathrm{~s}, 55^{\circ} \mathrm{C}$ for $30 \mathrm{~s}$ and $72{ }^{\circ} \mathrm{C}$ for $30 \mathrm{~s}$ followed by $10 \mathrm{~min}$ at $72{ }^{\circ} \mathrm{C}$ before a final hold at $4{ }^{\circ} \mathrm{C}$. Positive and negative control cultures (Acidithiobacillus caldus strain $\mathrm{KU}^{\mathrm{T}}$ and Acidocella facilis strain $\mathrm{PW}^{\mathrm{T}}$, respectively) and Acidimicrobium ferrooxidans (strains $\mathrm{ICP}^{\mathrm{T}}$ and $\mathrm{TH} 3$ ) were tested concurrently.

Analysis of $\mathbf{G}+\mathbf{C}$ content of chromosomal DNA. Cultures grown in $10 \mathrm{mM}$ ferrous iron $/ 0.02 \%$ yeast extract medium were harvested by centrifugation and washed twice with $100 \mathrm{mM}$ oxalic acid to remove ferric iron precipitates. Chromosomal DNA was purified by the technique described by Wilson (1987), and incorporated a caesium chloride gradient centrifugation stage. The DNA extracted from the gradients was dialysed against three changes of $0.1 \times \mathrm{SSC}(15 \mathrm{mM} \mathrm{NaCl}$ plus $1.5 \mathrm{mM} \mathrm{Na}_{3} \mathrm{C}_{6} \mathrm{H}_{5} \mathrm{O}_{7}$ ), and the ethidium bromide was extracted from the DNA with $0.1 \times$ SSC-saturated butanol. G $+\mathrm{C}$ contents were determined from melting temperatures of the DNA, which were determined with an HP 8453A UV-visible spectrophotometer connected to an HP 89090A Peltier temperature controller. The base composition of DNA was determined from its melting point by using the equation $\mathrm{G}+\mathrm{C}=2.44\left[\left(T_{m}-81.5\right)-(16.6 \log M)\right]$, where $T_{m}$ is the melting temperature of the DNA and $M$ is the molar concentration of the cations in the DNA suspension (Marmur \& Doty, 1962).

Phylogenetic analysis. Lysates of $\mathrm{T} 23^{\mathrm{T}}$ and $\mathrm{Y} 005^{\mathrm{T}}$ were prepared by resuspending bacterial pellets in lysis solution $(0.05 \mathrm{M} \mathrm{NaOH}$ and $0.25 \%$ SDS) and heating to $95{ }^{\circ} \mathrm{C}$ for $15 \mathrm{~min}$ before diluting tenfold with sterile MilliQ water. The $16 \mathrm{~S}$ rRNA genes were amplified by PCR using these templates as described previously (Okibe et al., 2003). The resulting products were purified using QIAquick spin columns (Qiagen) and sequenced using a Beckman Coulter dye terminator cycle sequencing kit and a CEQ8000 Genetic Analysis System. These 16S rRNA gene sequences (GenBank accession number AF251436 for T23 ${ }^{\mathrm{T}}$ and AY140237 for $\mathrm{Y}_{005}{ }^{\mathrm{T}}$ ) were compared with others in the GenBank database with the BLAST program (Altschul et al., 1997). Sequences from selected micro-organisms were obtained from GenBank and aligned with the T23 ${ }^{\mathrm{T}}$ and $\mathrm{Y} 005^{\mathrm{T}}$ gene sequences using ARB (Ludwig et al., 2004). This alignment was corrected manually and phylogenetic trees were constructed by neighbour-joining, DNA parsimony and maximumlikelihood algorithms in ARB. Each of the three methods gave trees of similar topology. The reliability of the phylogenetic relationships inferred was tested by bootstrap analysis on 1000 samples (Felsenstein, 1985), which yielded values better than $70 \%$ in all cases.

Chemotaxonomic analysis. Cultures of $\mathrm{T} 23^{\mathrm{T}}$ and $\mathrm{Y} 005^{\mathrm{T}}$ were grown at 30 or $37^{\circ} \mathrm{C}$, respectively, in a liquid medium at $\mathrm{pH} 2$ containing $10 \mathrm{mM}$ ferrous sulfate, $5 \mathrm{mM}$ glycerol and $0.02 \%$ yeast extract. Biomass was obtained by centrifugation and was sent to the Deutsche Sammlung von Mikroorganismen und Zellkulturen (DSMZ), Germany, for determination of fatty acids and structural analysis of the peptidoglycan of these bacteria. In addition, respiratory quinones were extracted from freeze-dried biomass following method three described by DiSpirito et al. (1983). The extracted quinones were subjected to HPLC analysis on a Dionex Acclaim 120 C18 reverse phase column $(150 \times 4.6 \mathrm{~mm})$ with a solvent of 80 parts methanol and 20 parts 2propanol at a flow rate of $1 \mathrm{ml} \mathrm{min}{ }^{-1}$. Quinones were detected by UV absorption at $248 \mathrm{~nm}$ for menaquinones and $275 \mathrm{~nm}$ for ubiquinones. Standards included menaquinone MK-6 and ubiquinone Q10 from Sigma-Aldrich, as well as those extracted from well-characterized bacterial strains. To confirm the identity of the menaquinones, the extracts were also subjected to mass spectrometry analysis using a Brucker high-resolution time of flight spectrometer.

\section{RESULTS}

\section{Growth on solid and in liquid media}

Colonies of $\mathrm{T} 23^{\mathrm{T}}$ displayed a 'fried egg'-like morphology on Feo solid medium, and grew poorly on both FeSo and iFeo solid media. Cells were rod-shaped, $1-3 \mu \mathrm{m}$ long by $0.5 \mu \mathrm{m}$ wide and motile, and did not produce endospores. Chains of three to five cells were common during exponential growth. Colonies of $\mathrm{Y}_{005^{\mathrm{T}}}$ on Feo solid medium contrasted with $\mathrm{T} 23^{\mathrm{T}}$ in being small, ironencrusted but not gelatinous, and having a distinct rhizoidal morphology. Similar morphologies of $\mathrm{Y}_{005}{ }^{\mathrm{T}}$ colonies were observed on FeSo medium and on iFeo medium, though they were much smaller on the latter.

In ferrous iron-containing liquid media, cultures of $\mathrm{T} 23^{\mathrm{T}}$ became increasingly turbid and orange-coloured (due to the accumulation of ferric iron) during incubation. In contrast, although colour change could also be used to indicate iron oxidation in cultures of $\mathrm{Y}_{005}{ }^{\mathrm{T}}$, the cultures did not become turbid, as the bacteria grew as visible flocs approx. 1-3 $\mathrm{mm}$ in diameter. Microscopic examination showed that isolate $\mathrm{Y}_{005}{ }^{\mathrm{T}}$ grew as long entangled filaments (Fig. 1). Occasionally single cells were observed; these were 3-4 $\mu \mathrm{m}$ long and approx. $0.5 \mu \mathrm{m}$ wide. Cells were nonmotile and were not observed to form endospores.

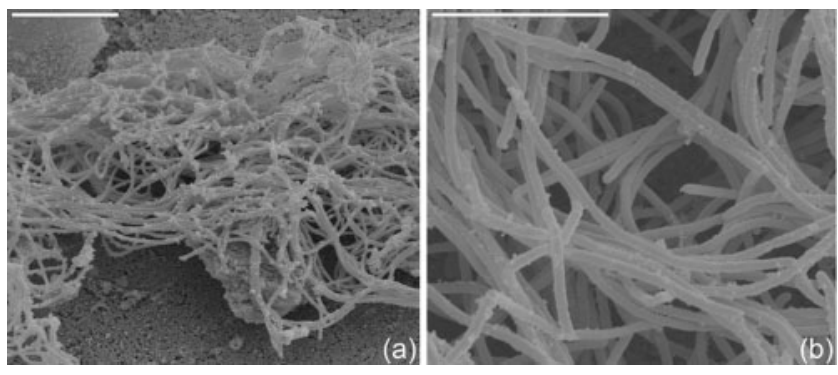

Fig. 1. Scanning electron micrographs of (a) a $Y 005^{\top}$ floc and (b)

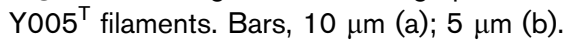


The $\mathrm{pH}$ optimum and minimum for growth of isolate $\mathrm{T} 23^{\mathrm{T}}$ were 2.0 and 1.4, respectively, and its temperature optimum was $35^{\circ} \mathrm{C}$. Isolate $\mathrm{T} 23^{\mathrm{T}}$ grew at $37^{\circ} \mathrm{C}$, but not at $45^{\circ} \mathrm{C}$. In the case of isolate $\mathrm{Y} 05^{\mathrm{T}}$, the $\mathrm{pH}$ growth optimum was 1.8 and minimum $\mathrm{pH}$ 1.6. Its temperature optimum and maxima were $43{ }^{\circ} \mathrm{C}$ and $50{ }^{\circ} \mathrm{C}$, respectively. Under optimum conditions of $\mathrm{pH}$ and temperature, culture doubling times of isolate $\mathrm{T} 23^{\mathrm{T}}$ and $\mathrm{Y}_{005}{ }^{\mathrm{T}}$ were 6.3 and $3.0 \mathrm{~h}$, respectively.

\section{Oxidation of iron, sulfur and pyrite}

Both isolates $\mathrm{T} 23^{\mathrm{T}}$ and $\mathrm{Y} 005^{\mathrm{T}}$ catalysed the dissimilatory oxidation of ferrous iron, but not of elemental sulfur (data not shown). Pyrite was oxidized by both isolates, but only in media amended with yeast extract (Supplementary Fig. S1, available in IJSEM Online). Even in yeast extractcontaining medium pyrite oxidation by $\mathrm{T} 23^{\mathrm{T}}$ was much slower than that by the chemolithotrophic acidophile Acidithiobacillus ferrooxidans (Supplementary Fig. S1a).

\section{Utilization of organic substrates}

Both isolates $\mathrm{T} 23^{\mathrm{T}}$ and $\mathrm{Y} 005^{\mathrm{T}}$ displayed limited growth on single organic substrates. In both cases, none of the sugars tested were utilized by the bacteria. Growth yields of isolate $\mathrm{T} 23^{\mathrm{T}}$ were greater in media containing glycerol, citric acid and glutamic acid than in control cultures, while only glycerol and ethanol, among the potential substrates tested, were used by isolate $\mathrm{Y}_{005}{ }^{\mathrm{T}}$. Acetic acid was highly toxic to both bacteria, inhibiting the growth of $\mathrm{T} 23^{\mathrm{T}}$ at $1 \mathrm{mM}$ and that of $\mathrm{Y}_{00}{ }^{\mathrm{T}}$ at $100 \mu \mathrm{M}$. Isolate $\mathrm{T} 23^{\mathrm{T}}$ grew in $5 \mathrm{mM}$ glycerol/100 $\mu \mathrm{M}$ ferrous sulfate liquid medium, confirming that it is not auxotrophic. However, attempts to grow isolate $\mathrm{Y}_{005}{ }^{\mathrm{T}}$ in yeast extract-free media were unsuccessful, indicating that it has a requirement for one or more growth factors.

\section{Ferric iron reduction}

Both isolates $\mathrm{T} 23^{\mathrm{T}}$ and $\mathrm{Y} 005^{\mathrm{T}}$ were able to reduce ferric iron under anaerobic conditions, using glycerol as an electron donor (Supplementary Fig. S2, available in IJSEM Online). No abiotic iron reduction occurred in uninoculated controls.

\section{Effect of iron concentrations on biomass yields and growth rates}

Growth yields of isolate $\mathrm{T} 23^{\mathrm{T}}$ in cultures containing the same amount of yeast extract but different concentrations of either ferrous or ferric iron are shown in Fig. 2. Biomass yields were similar, irrespective of the form of iron provided, when iron concentrations were low (0.1 and $1.0 \mathrm{mM})$, but at higher concentrations $(25$ and $50 \mathrm{mM})$ yields were significantly greater $(P<0.001)$ when ferrous rather than ferric iron was added to cultures. No correlations between yields of $\mathrm{T} 23^{\mathrm{T}}$ and ferrous iron concentrations were found when yeast extract was present at low $(0.001-0.002 \%, w / v)$ concentrations, presumably because cultures were carbon limited-rather than energy-

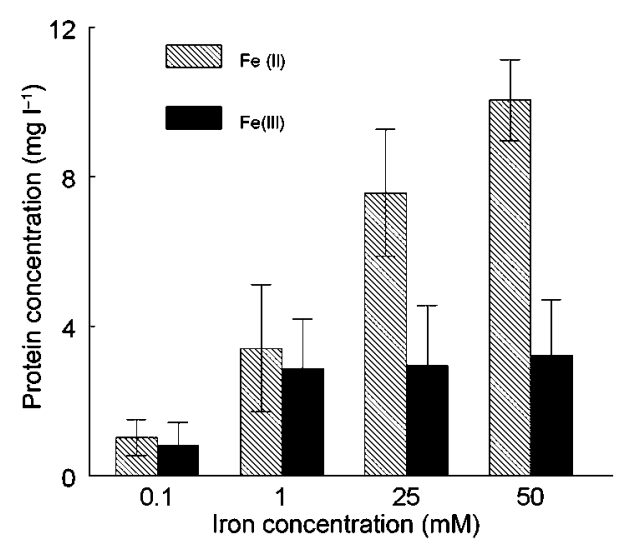

Fig. 2. Effect of different concentration of ferrous and ferric iron on the growth yields of isolate $T 23^{\top}$, grown in the presence of $0.02 \%(\mathrm{w} / \mathrm{v})$ yeast extract ( $n=3$ for each treatment).

limited under such conditions (data not shown). Growth rates of isolate $\mathrm{T} 23^{\mathrm{T}}$ were much faster $\left(0.081-0.095 \mathrm{~h}^{-1}\right)$ in liquid media that contained $10-50 \mathrm{mM}$ ferrous iron than in corresponding cultures that contained either ferric iron (at $1-50 \mathrm{mM}$ ) or $1 \mathrm{mM}$ ferrous iron $\left(0.049-0.055 \mathrm{~h}^{-1}\right)$. No comparable data were obtained for isolate $\mathrm{Y}_{005^{\mathrm{T}}}$.

\section{Heavy metal tolerance}

Both Gram-positive isolates were able to grow in media containing elevated concentrations of the heavy metals tested. Isolate $\mathrm{T} 23^{\mathrm{T}}$ grew in $200 \mathrm{mM}$ of both ferrous and ferric iron. Growth also occurred in the presence of $150 \mathrm{mM}$ (but not $200 \mathrm{mM}$ ) copper, but zinc was more toxic (50 mM inhibited growth). Isolate $\mathrm{Y}_{005^{\mathrm{T}}}$ grew in $200 \mathrm{mM}$ concentrations of all the heavy metals tested, except ferric iron which inhibited growth at $100 \mathrm{mM}$.

\section{$\mathrm{CO}_{2}$ fixation}

Neither $\mathrm{T} 23^{\mathrm{T}}$ nor $\mathrm{Y}_{00} 5^{\mathrm{T}}$ was able to grow in organic carbonfree liquid media. While there was limited oxidation of ferrous iron in the first transfer of isolates into ferrous sulfate medium, no increase in cell numbers was recorded. In contrast to Acidithiobacillus ferrooxidans, no assimilation of $\mathrm{CO}_{2}$ was observed in cultures of isolate T23 ${ }^{\mathrm{T}}$ (Fig. 3).

No RuBisCO genes were amplified from cell lysates of either $\mathrm{T} 23^{\mathrm{T}}$ or $\mathrm{Y}_{005}{ }^{\mathrm{T}}$, though both $c b b L$ and $c b b M$ genes were successfully amplified from Acidithiobacillus caldus lysates, and neither from Acidocella facilis. Only $c b b L$ genes were amplified successfully from both strains of Acidimicrobium ferrooxidans.

\section{Genotypic traits}

The $\mathrm{G}+\mathrm{C}$ contents of genomic DNA were determined as $54.9 \pm 0.3 \mathrm{~mol} \%$ for $\mathrm{T} 23^{\mathrm{T}}$ and $50.2 \pm 0.8 \mathrm{~mol} \%$ for $\mathrm{Y}_{005} 5^{\mathrm{T}}$. The published value for Acidimicrobium ferrooxidans is 67$69 \mathrm{~mol} \%$ (Clark \& Norris, 1996). 



Fig. 3. Comparison of $\mathrm{CO}_{2}$ uptake by isolate $\mathrm{T}^{2} 3^{\top}(\boldsymbol{\Lambda}, \triangle)$ and the mesophilic chemoautotroph Acidithiobacillus ferrooxidans ATCC $23270^{\top}(\boldsymbol{\nabla}, \nabla)$. Data shown are from: (a) batch cultures in $20 \mathrm{mM}$ ferrous iron medium (with or without $0.02 \% \mathrm{w} / \mathrm{v}$ yeast extract); (b) by harvested cells. Solid symbols show data from cultures amended with $0.02 \%(\mathrm{w} / \mathrm{v})$ yeast extract, and hollow symbols in yeast extract-free medium.

The $16 \mathrm{~S}$ rRNA gene sequences of $\mathrm{T} 23^{\mathrm{T}}$ and $\mathrm{Y} 005^{\mathrm{T}}$ have all the signature nucleotides and nucleotide pairs to indicate that they belong to the family Acidimicrobiaceae, as proposed by Stackebrandt et al. (1997). The 16S rRNA gene sequences from $\mathrm{T} 23^{\mathrm{T}}$ and $\mathrm{Y} 005^{\mathrm{T}}$ are $94.2 \%$ identical to each other, and are 92.9 and $90.9 \%$ identical to that from Acidimicrobium ferrooxidans, respectively. Phylogenetic analyses placed these two bacteria in a group that includes other iron-oxidizing acidophiles, including the type genus of the family, Acidimicrobium, and isolates CS1, KP1 and WJ25 obtained from acid mine drainage sites in the UK (Fig. 4). In addition, this group includes bacteria that have been detected by molecular means in acid mine drainage environments or mineral leaching bioreactors (Fig. 4).

\section{Chemotaxonomic traits}

Both isolates $\mathrm{T} 23^{\mathrm{T}}$ and $\mathrm{Y} 005^{\mathrm{T}}$ contained meso-diaminopimelic acid in the peptidoglycan, and the peptidoglycan type was Al $\gamma$ (Schleifer \& Kandler, 1972). The dominant fatty



Fig. 4. Maximum-likelihood tree showing the relationship of Ferrimicrobium acidiphilum $\mathrm{T} 23^{\top}$ and Ferrithrix thermotolerans

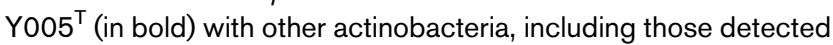
in acidic sites by molecular means. The tree was rooted with the 16S rRNA gene sequence from Acidimicrobidae bacterium Ellin7143 (GenBank accession number AY673309). GenBank accession numbers for other actinobacteria are given in parentheses. Bar, 1 nucleotide substitution per 100 nucleotides.

acid of isolate $\mathrm{T} 23^{\mathrm{T}}$ was $\mathrm{i}-\mathrm{C}_{16: 0}(64.23 \%)$; other fatty acids were $\mathrm{i}-\mathrm{C}_{14: 0}(10.83 \%), \mathrm{C}_{14: 0}(0.24 \%), \mathrm{i}-\mathrm{C}_{15: 0}(5.03 \%)$, ai$\mathrm{C}_{15: 0}(5.14 \%), \mathrm{C}_{15: 0}(0.32 \%), \mathrm{i}-\mathrm{C}_{14: 0} 3-\mathrm{OH}(1.20 \%)$, i$\mathrm{C}_{16: 1} \mathrm{H}(2.49 \%), \mathrm{C}_{16: 0}(0.48 \%)$, ai- $\mathrm{C}_{17: 1} \omega 9 c(0.19 \%)$, i$\mathrm{C}_{17: 0}(0.39 \%)$, ai- $\mathrm{C}_{17: 0}(3.18 \%), \mathrm{C}_{17: 1} \omega 6 c(5.97 \%)$, and $\mathrm{i}-\mathrm{C}_{18: 0}(0.30 \%) . \mathrm{Y}^{2} 05^{\mathrm{T}}$ shared the same dominant fatty acid as $\mathrm{T} 23^{\mathrm{T}}$, namely $\mathrm{i}-\mathrm{C}_{16: 0}(90.13 \%)$, but differed in the composition of the minor fatty acids, which included $\mathrm{C}_{12: 0}$ $(0.16 \%)$, i- $\mathrm{C}_{14: 0}(0.54 \%), \quad \mathrm{i}-\mathrm{C}_{15: 0}(1.30 \%)$, ai- $\mathrm{C}_{15: 0}$ $(0.73 \%), \mathrm{C}_{15: 0}(0.88 \%), \mathrm{i}-\mathrm{C}_{14: 0} 3-\mathrm{OH}(0.51 \%), \mathrm{i}-\mathrm{C}_{16: 1} \mathrm{H}$ $(1.45 \%), \mathrm{C}_{16: 0}(0.63 \%)$, ai- $\mathrm{C}_{17: 0}(0.99 \%), \mathrm{C}_{18: 1} \omega 9 c$ $(0.19 \%), \mathrm{C}_{18: 1} \omega 7 c(0.25 \%)$, and $\mathrm{C}_{18: 0}(0.34 \%)$. The major respiratory quinone of $\mathrm{T} 23^{\mathrm{T}}$ was a menaquinone with eight isoprenoid side chains, five of which were saturated [e.g. MK-8(H10)]. In addition, small amounts of MK-8(H10) with one or two methyl groups were also detected, along with a trace of MK-8. Attempts to extract and identify respiratory quinones from $\mathrm{Y}_{005}{ }^{\mathrm{T}}$ by the authors and by staff at the DSMZ were all unsuccessful.

\section{DISCUSSION}

The two bacteria described have many characteristics in common with the current sole cultivated species of the 
Acidimicrobidae (Acidimicrobium ferrooxidans), most notably that they are all obligately acidophilic bacteria that catalyse the dissimilatory oxidation of ferrous iron and reduction of ferric iron. Key differences are that both $\mathrm{T} 23^{\mathrm{T}}$ and $\mathrm{Y}_{005}{ }^{\mathrm{T}}$ are obligate heterotrophs, while Acidimicrobium ferrooxidans can fix $\mathrm{CO}_{2}$, albeit relatively inefficiently compared with other acidophiles such as Acidithiobacillus ferrooxidans. Another physiological trait that differentiates $\mathrm{T} 23^{\mathrm{T}}$ from both Acidimicrobium ferrooxidans and $\mathrm{Y} 005^{\mathrm{T}}$ is that the former is mesophilic while the latter are both moderate thermophiles. In terms of nutrition, both $\mathrm{T} 23^{\mathrm{T}}$ and $\mathrm{Y}_{005^{\mathrm{T}}}$ can grow using some defined organic carbon compounds, such as glycerol, as sole carbon and energy sources [though the latter requires some unidentified growth factor(s)]; heterotrophic growth of Acidimicrobium ferrooxidans on yeast extract has also been reported (Clark \& Norris, 1996). Isolate $\mathrm{T} 23^{\mathrm{T}}$, like Acidimicrobium ferrooxidans, can utilize the energy from oxidizing ferrous iron, though this was not ascertained in the case of $\mathrm{Y}_{005^{\mathrm{T}}}$. Given the phenotypic and phylogenetic differences of these two isolates to each other, and also to Acidimicrobium ferrooxidans, it is apparent that they represent species of two novel genera, and the names Ferrimicrobium acidiphilum gen. nov., sp. nov. and Ferrithrix thermotolerans gen. nov., sp. nov. are proposed for isolates $\mathrm{T} 23^{\mathrm{T}}$ and $\mathrm{Y} 005^{\mathrm{T}}$, respectively.

Bacteria closely related to Ferrimicrobium acidiphilum appear to have worldwide distribution. Besides the isolates referred to by Johnson \& Roberto (1997), BLAST searches show that similar clones have been detected in mine waters in China and Iron Mountain, California, USA. DGGE bands of amplified 16S rRNA genes from mine waters draining coal spoil and the Río Tinto, Spain (GonzalezToril et al., 2003) have also been identified as Ferrimicrobium acidiphilum-like bacteria. In contrast, Ferrithrix thermotolerans has not yet been detected outside of geothermal regions of Yellowstone National Park. The closest $(95.4 \%$ identity) $16 \mathrm{~S}$ rRNA gene to that of Ferrithrix thermotolerans is of a bacterium (WJ25) isolated from mine water in Cornwall, England, UK (Hallberg \& Johnson, 2005).

Other bacterial isolates from acidic, metal-rich environments identified as Acidimicrobidae have been described, though not fully characterized (e.g. Hallberg et al., 2006), which appear (on the basis of 16S rRNA gene identities) to be distinct from both novel species described here, and also from Acidimicrobium ferrooxidans. Some of these isolates appeared to be morphologically and physiologically similar to isolate 'CCH7' (Johnson et al., 1992), which was not sequenced at the time, and was subsequently lost. Interestingly, one of the characteristics described for $\mathrm{CCH} 7$ was its tendency to grow as extended filaments, forming macroscopic flocs and streamers in liquid culture, somewhat similar to Ferrithrix thermotolerans. The unclassified isolates described by Hallberg et al. (2006) were also acidophilic iron oxidizers. The Acidimicrobidae clones described by Montalvo et al. (2005) were obtained from marine sponges, where neither extremely low $\mathrm{pH}$ nor elevated ferrous iron would be anticipated. The intriguing prospect of novel Acidimicrobidae with very contrasting physiological traits to those described to date awaits the successful isolation of bacteria represented by these clones.

\section{Description of Ferrimicrobium gen. nov.}

Ferrimicrobium (Fer.ri.mi.cro'bi.um. L. neut. n. ferrum iron; N.L. neut. n. microbium microbe; N.L. neut. n. Ferrimicrobium iron microbe).

Cells are motile rods, Gram-negative, and do not form spores. Acidophilic, mesophilic and obligately heterotrophic. Capable of oxidation and reduction of iron and oxidation of pyrite. Grows with yeast extract or a limited range of organic compounds. Sequence analysis of the $16 \mathrm{~S}$ rRNA gene places the genus within the subclass of Acidimicrobidae in the Actinobacteria. The peptidoglycan type is $\mathrm{A} 1 \gamma$. The major fatty acids are $\mathrm{i}-\mathrm{C}_{16: 0}, \mathrm{i}-\mathrm{C}_{14: 0}$, i- $\mathrm{C}_{15: 0}$, ai- $\mathrm{C}_{15: 0}$ and $\mathrm{C}_{17: 1} \omega 6 \mathrm{c}$. The dominant menaquinone is MK-8(H10), with minor amounts of MK-8 and MK-8(H10) containing one or two methyl groups also detected. The $\mathrm{G}+\mathrm{C}$ content of the genomic DNA is approx. $55 \mathrm{~mol} \%$. The type species is Ferrimicrobium acidiphilum.

\section{Description of Ferrimicrobium acidiphilum sp. nov.}

Ferrimicrobium acidiphilum (a.ci.di'phi.lum. L. adj. acidus sour; N.L. neut. n. acidum acid; Gr. adj. philos loving; N.L. neut. adj. acidiphilum acid-loving).

Cells are rod-shaped, $1-3 \mu \mathrm{m}$ in length and $0.5 \mu \mathrm{m}$ in diameter, motile and do not form endospores. Gramnegative. Form gelatinous colonies of approx. $1-3 \mathrm{~mm}$ diameter, and with ferric iron deposits in centre on ferrous iron overlay plates. Mesophilic, optimum growth at $35{ }^{\circ} \mathrm{C}$ (maximum $37{ }^{\circ} \mathrm{C}$ ) and acidophilic, optimum growth at pH 2 (minimum pH 1.4). Obligately heterotrophic; growth on yeast extract and a limited range of defined organic substrates including glycerol, citric acid and glutamic acid. Capable of oxidation of ferrous iron and pyrite, and reduction of ferric iron only in the presence of organic carbon. The dominant menaquinone is MK-8 (H10), with minor amounts of MK-8 and MK-8(H10) containing one or two methyl groups also present. The major fatty acids are i- $\mathrm{C}_{16: 0}, \mathrm{i}-\mathrm{C}_{14: 0}, \mathrm{i}-\mathrm{C}_{15: 0}$, ai- $\mathrm{C}_{15: 0}$, and $\mathrm{C}_{17: 1} \omega 6 c$, with other minor fatty acids. The peptidoglycan type is Al $\gamma$. Chromosomal DNA base composition is $54.9 \pm 0.3 \mathrm{~mol} \% \mathrm{G}+\mathrm{C}$. Sequencing of the $16 \mathrm{~S}$ rRNA gene (GenBank accession number AF251436) indicates that Ferrimicrobium acidiphilum belongs to the class Actinobacteria and subclass Acidimicrobidae. Found in acidic iron-rich environments associated with the oxidation of sulfide minerals, such as acid mine drainage waters and bioleachate liquors. 
The type strain is $\mathrm{T}^{2} 3^{\mathrm{T}}\left(=\mathrm{DSM} 19497^{\mathrm{T}}=\mathrm{ATCC}\right.$ BAA$\left.1647^{\mathrm{T}}\right)$.

\section{Description of Ferrithrix gen. nov.}

Ferrithrix (Fer.ri.thr'ix. L. neut. n. ferrum iron; Gr. fem. n. thrix hair, thread; N.L. fem. n. Ferrithrix iron thread).

Grows as filaments (occasionally as single rods), Gramnegative, and does not form spores. Acidophilic, moderately thermophilic, and obligately heterotrophic. Capable of oxidation and reduction of iron. Grows on yeast extract, glycerol or ethanol. A growth factor (or factors), obtained from yeast extract is (are) required for growth. Sequence analysis of the 16S rRNA gene places the genus within the subclass of Acidimicrobidae in the Actinobacteria. The major fatty acid is $\mathrm{i}-\mathrm{C}_{16: 0}$. The peptidoglycan type is $\mathrm{A} 1 \gamma$. The $\mathrm{G}+\mathrm{C}$ content of the genomic DNA is approx. $50 \mathrm{~mol} \%$. The type species is Ferrithrix thermotolerans.

\section{Description of Ferrithrix thermotolerans sp. nov.}

Ferrithrix thermotolerans (ther.mo.to'le.rans. Gr. n. thermê heat; L. part. adj. tolerans tolerating; N.L. part. adj. thermotolerans heat-tolerating, able to tolerate high temperatures).

Generally grows as filaments forming visible flocs (approx. $1-3 \mathrm{~mm}$ in diameter), though occasionally single, rodshaped cells are observed (3-4 $\mu \mathrm{m}$ in length and $0.5 \mu \mathrm{m}$ in diameter). Non-motile and does not form endospores. Gram-negative. Moderately thermophilic, optimal growth at $43{ }^{\circ} \mathrm{C}$ (maximum $50{ }^{\circ} \mathrm{C}$ ) and acidophilic, optimal growth at $\mathrm{pH} 1.8$ (minimum $\mathrm{pH}$ 1.6). Colonies are small (1-2 $\mathrm{mm}$ in diameter), rhizoidal and iron-encrusted in ferrous iron, ferrous iron/tetrathionate and inorganic iron solid overlay media. Obligately heterotrophic, capable of growth with yeast extract, glycerol and ethanol. An unknown growth factor(s) supplied by yeast extract is (are) required for growth. Also able to oxidize and reduce iron. The major fatty acid is $\mathrm{i}-\mathrm{C}_{16: 0}$, with other fatty acids present in minor amounts. The peptidoglycan type is $\mathrm{A} 1 \gamma$. The $\mathrm{G}+\mathrm{C}$ content of the chromosomal DNA is $50.2 \pm$ $0.8 \mathrm{~mol} \%$. Found in geothermal springs. Sequencing of the $16 \mathrm{~S}$ rRNA gene (GenBank accession number AY140237) indicates that Ferrithrix thermotolerans belongs to the class Actinobacteria and subclass Acidimicrobidae.

The type strain is strain $\mathrm{Y}_{005}{ }^{\mathrm{T}}\left(=\mathrm{DSM} 19514^{\mathrm{T}}=\mathrm{ATCC}\right.$ BAA- $\left.1645^{\mathrm{T}}\right)$.

\section{ACKNOWLEDGEMENTS}

This work was carried out (in part) in the frame of BioMinE (European project contract NMP1-CT-500329-1). The authors acknowledge financial support given to this project by the European Commission under the Sixth Framework Programme for Research and Development. D. B. J. is grateful to the Royal Society (UK) for the provision of an Industrial Fellowship. We would also like to thank Dr Jean Euzéby (École Nationale Vétérinaire, Toulouse, France) for his expert advice on bacterial nomenclature, and Dr Barry
Grail and Mr Denis Williams (Bangor University, Bangor, UK) for their help with mass spectrometry.

\section{REFERENCES}

Alfreider, A., Vogt, C., Hoffman, D. \& Babel, W. (2003). Diversity of ribulose 1,5-bisphosphate carboxylase/oxygenase large-subunit genes from groundwater and aquifer microorganisms. Microb Ecol 45, 317-328.

Altschul, S. F., Madden, T. L., Schaffer, A. A., Zhang, J., Zhang, Z., Miller, W. \& Lipman, D. J. (1997). Gapped BLAST and PSI-BLAST: a new generation of protein database search programs. Nucleic Acids Res 25, 3389-3402.

Bacelar-Nicolau, P. \& Johnson, D. B. (1999). Leaching of pyrite by acidophilic heterotrophic iron-oxidizing bacteria in pure and mixed cultures. Appl Environ Microbiol 65, 585-590.

Bradford, M. M. (1976). A rapid and sensitive method for the quantitation of microgram quantities of protein utilizing the principle of protein-dye binding. Anal Biochem 72, 248-254.

Brierley, J. A. (1978). Thermophilic iron-oxidizing bacteria found in copper leaching dumps. Appl Environ Microbiol 36, 523-525.

Clark, D. A. \& Norris, P. R. (1996). Acidimicrobium ferrooxidans gen. nov., sp. nov.: mixed culture ferrous iron oxidation with Sulfobacillus species. Microbiology 142, 785-790.

DiSpirito, A. A., Loh, H. T. \& Tuovinen, O. H. (1983). A novel method for the isolation of bacterial quinones and its application to appraise the ubiquinone composition of Thiobacillus ferrooxidans. Arch Microbiol 135, 77-80.

Felsenstein, J. (1985). Confidence limits on phylogenies: an approach using the bootstrap. Evolution 39, 783-791.

Ghauri, M. A. \& Johnson, D. B. (1991). Physiological diversity amongst some moderately thermophilic iron-oxidising bacteria. FEMS Microbiol Ecol 85, 327-334.

Gonzalez-Toril, E., Llobet-Brossa, E., Casamayor, E. O., Amann, R. \& Amils, R. (2003). Microbial ecology of an extreme acidic environment, the Tinto River. Appl Environ Microbiol 69, 4853-4865.

Hallberg, K. B. \& Johnson, D. B. (2005). Microbiology of a wetland ecosystem constructed to remediate mine drainage from a heavy metal mine. Sci Total Environ 338, 53-66.

Hallberg, K. B., Coupland, K., Kimura, S. \& Johnson, D. B. (2006). Macroscopic "acid streamer" growths in acidic, metal-rich mine waters in north Wales consist of novel and remarkably simple bacterial communities. Appl Environ Microbiol 72, 2022-2030.

Jenkins, D. A. \& Johnson, D. B. (1993). Abandoned metal mines: a unique mineralogical and microbiological resource. J Russell Soc 5, $40-44$.

Johnson, D. B. \& Hallberg, K. B. (2007). Techniques for detecting and identifying acidophilic mineral-oxidising microorganisms. In Biomining, pp. 237-261. Edited by D. E. Rawlings \& D. B. Johnson. Heidelberg: Springer.

Johnson, D. B. \& Roberto, F. F. (1997). Heterotrophic acidophiles and their roles in the bioleaching of sulfide minerals. In Biomining: Theory, Microbes and Industrial Processes, pp. 259-280. Edited by D. E. Rawlings. Berlin, New York: Springer.

Johnson, D. B., Ghauri, M. A. \& Said, M. F. (1992). Isolation and characterisation of an acidophilic heterotrophic bacterium capable of oxidizing ferrous iron. Appl Environ Microbiol 58, 1423-1428.

Johnson, D. B., Okibe, N. \& Roberto, F. F. (2003). Novel thermoacidophiles isolated from geothermal sites in Yellowstone National Park: physiological and phylogenetic characteristics. Arch Microbiol 180, 60-68. 
Lovley, D. R. \& Phillips, E. J. P. (1987). Rapid assay for microbially reducible ferric iron in aquatic sediments. Appl Environ Microbiol 53, 1536-1540.

Ludwig, W., Strunk, O., Westram, R., Richter, L., Meier, H., Yadhukumar, Buchner, A., Lai, T., Steppi, S. \& other authors (2004). ARB: a software environment for sequence data. Nucleic Acids Res 32, 1363-1371.

Marmur, J. \& Doty, P. (1962). Determination of base composition of deoxyribonucleic acid from its thermal denaturation temperature. J Mol Biol 5, 109-118.

Montalvo, N. F., Mohamed, M. N., Enticknap, J. J. \& Hill, R. T. (2005). Novel actinobacteria from marine sponges. Antonie van Leeuwenhoek 87, 29-36.
Okibe, N., Gericke, M., Hallberg, K. B. \& Johnson, D. B. (2003). Enumeration and characterization of acidophilic microorganisms isolated from a pilot plant stirred tank bioleaching operation. Appl Environ Microbiol 69, 1936-1943.

Schleifer, K. H. \& Kandler, O. (1972). Peptidoglycan types of bacterial cell walls and their taxonomic implications. Bacteriol Rev 36, 407-477.

Stackebrandt, E., Rainey, F. A. \& Ward-Rainey, N. L. (1997). Proposal for a new hierarchic classification system, Actinobacteria classis nov. Int J Syst Bacteriol 47, 479-491.

Wilson, K. (1987). Preparation of genomic DNA from bacteria. In Current Protocols in Molecular Biology, pp. 2.4.1-2.4.5. Edited by F. M. Ausubel, R. Brent, R. E. Kingston, D. D. Moore, J. G. Seidman, J. A. Smith \& K. Struhl. New York: Green Publishing \& Wiley-Interscience. 